\title{
Women's perceptions and practices regarding their rights to reproductive health
}

\author{
K. Abou Shabana, ${ }^{1}$ M. El-Shiek, ${ }^{1}$ M. El-Nazer ${ }^{2}$ and N. Samir ${ }^{1}$
}

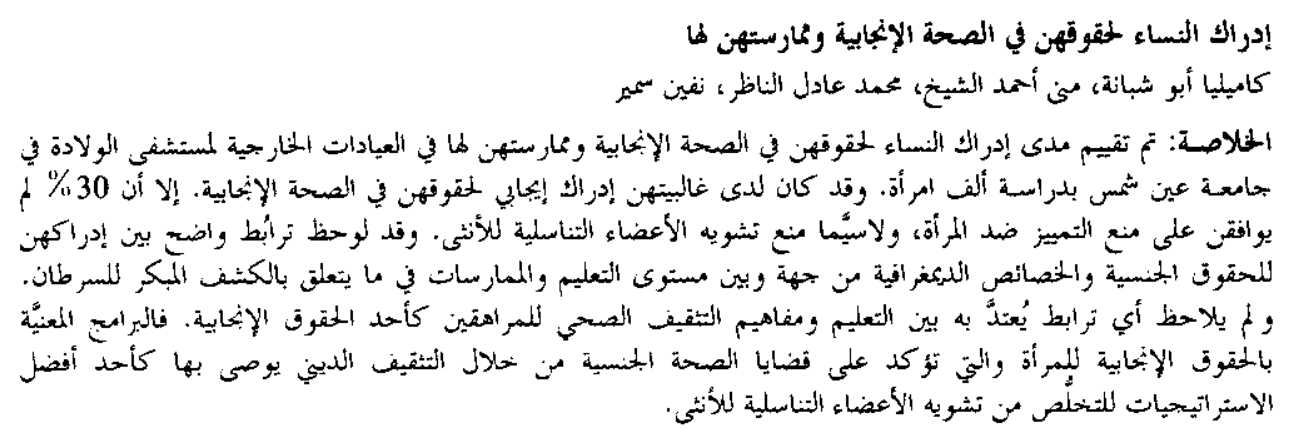

ABSTRACT At the outpatient clinic of Ain Shams University Maternity Hospital, perceptions and practices of 1000 women regarding their reproductive health rights (reproductive rights) were evaluated. The majority had positive perceptions about their rights to reproductive health; however, $30 \%$ disagreed with prohibitions of discrimination against women, particularly prohibitions of female genital mutilation (FGM). A significant association was found between perceptions of sexual rights and demographic characteristics and between education and practices regarding early detection of cancer. No significant association was found between education and concepts of adolescent health education as a reproductive right. Programmes about women's reproductive rights that emphasize the issue of sexual health through religious education are recommended as one of the best strategies for the eradication of FGM.

Conceptions et pratiques des femmes concernant leurs droits à la santé génésique

RESUME Dans le service de consultations externes de la Maternité universitaire d'Ain Shams, les conceptions et pratiques de 1000 femmes concernant leurs droits à la santé génésique (droits reproductifs) ont fait l'objet d'une évaluation. Dans la majorité des cas, elles avaient une conception positive de leurs droits à la santé génésique ; toutefois, $30 \%$ étaient en désaccord avec les interdictions de discrimination envers les femmes, en particulier l'interdiction des mutilations génitales féminines. Une association significative a été constatée entre les conceptions des droits sexuels et les caractéristiques démographiques et entre l'instruction et les pratiques concernant la détection précoce du cancer. Aucune association importante n'a été constatée entre l'instruction et la conception de l'éducation sanitaire des adolescents en tant que droit reproductif. Les programmes sur les droits reproductifs des femmes qui mettent en avant la question de la santé sexuelle par le biais de l'éducation religieuse sont recommandés comme l'une des meilleures stratégies pour l'éradication des mutilations génitales féminines.

'Department of Obstetrics and Gynaecology; 'Faculty of Nursing. Ain Shams University, Cairo, Egypt. Received: 08/04/02; accepted: 14/07/02 


\section{Introduction}

In 2000 in Egypt, a national study on maternal mortality reported that 84 women die per 100000 live births each year [I]. As women are an important resource, their reproductive health should be supported, protected and considered a crucial part of the general health of the community [2]. Reproductive health ( $\mathrm{RH}$ ) is the state of complete physical and social well-being in all aspects of the reproductive system and is not merely the absence of disease or disability. RH, therefore, implies that people are able to have a satisfying and safe sexual life, to reproduce and to have the freedom to decide when and how often to do so [3]. Reproductive rights are an integral and indivisible part of universal human rights. Individuals have a right to information, education and the means to implement their reproductive choices. They also have the right to attain the highest standard of sexual and reproductive health and the right to make decisions concerning reproduction free of discrimination, coercion or violence $[4,5]$.

Reproductive rights are supported by the teachings of the Holy Quran and the sayings of the Prophet Muhammad 㗪. In fact, Islam is interested in the reproductive rights of women from the moment they are born. It forbade the pre-Islamic practice of burying young girls alive and ensured their right to live. Furthermore, Islam guarantees the right of life to the fetus by forbidding abortion [5]. Within the framework of Islamic teachings, married couples have a reproductive right to a responsible, satisfying and safe sexual life [6]. Islam encourages sexual foreplay before intercourse and married couples are encouraged to wait for each other until both have satisfied their desire [7].
At the Fourth Conference on Women in Beijing in 1995, female genital mutilation (FGM) was grouped with other forms of violence against women [2]. The international community identified the need for urgent action against such violence including sexual abuse, rape of women and children, HIV/AIDS, teenage pregnancy, harmful practices like FGM, population overgrowth and poverty, mortality and morbidity, in addition to the exclusion of women from educational, economic and social opportunities [4].

In Egypt, the National Council for Women (NCW) was established in 2000 by Presidential Decree No. 90 [8] to promote and empower Egyptian women into active roles in social and economic growth and to organize awareness-raising programmes about women's reproductive rights. The decree banned the employment of women in hard labour jobs that affect their health (Article 153) and gave working mothers who are employed for a minimum of 6 months the right to take 50 days leave with full salary. This right can be repeated 3 times during the course of employment. The decree also prohibited the employment of pregnant women 40 days before delivery (Article 154). Working women furthermore have the right to take breaks during the workday to feed infants without decrease in salary. Other resolutions regarding Egyptian women and girls are documented in international agreements and national legislation. For example, women have the right to receive benefits from the medical insurance system according to the 1975 Law of Social Insurance No. 79. This includes treatment and medical care, hospitalization, investigation and necessary care for mothers during and after labour. The Egyptian Personal Affairs Law determines the conditions of competency for

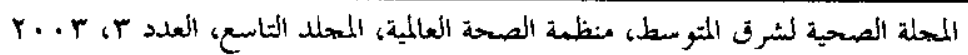


marriage, such as age (16 years for females and 18 years for males). In addition, the Egyptian woman consents to marriage and attends the signing of the marriage document in person or assigns someone on her behalf.

Women's perceptions define their health-seeking behaviours and are mirrors of their use of their reproductive rights [9]. For our study, perception was defined as the process of acquiring information about the environment through the senses and interpreting the sensory input in a meaningful way [10]. Women's perceptions of their reproductive rights depend on many cognitive, cultural, emotional, social and political factors. Nurses, for example, have played an important role in improving women's perception of reproductive rights and influencing their decision-making in the area of sexuality and reproduction [II].

The long-standing neglect of women's reproductive rights is now receiving attention because of tragically high maternal mortality and morbidity rates in developing countries [12]. Egyptian women have struggled for a long time to gain their reproductive rights as citizens $[8]$, and as research plays an important role in increasing attention to the status of women, this study investigated women's perceptions and use of their reproductive rights. We based our study on the hypothesis that the majority of Egyptian women had negative perceptions of their reproductive rights. We further hypothesized that there was a difference in concepts and use of reproductive rights between women in urban and rural areas and that education affected both.

\section{Methods}

The study took place in the Outpatient Clinic at Ain Shams University Maternity Hospital from 1 December 1999 to $1 \mathrm{De}$ cember 2000. This setting was chosen because of the large numbers of people seen there each year (approximately 10000 women/year). A convenience sample of 1000 women of reproductive age with different education levels and occupations were included in this descriptive crosssectional study.

A structured interviewing questionnaire in two parts (50 questions) was designed based on a literature review. The first part covered general demographic data such as age, educational level, occupation, religion and residence. The second part covered the women's concepts and practices and included questions about the following reproductive rights: marriage and having a family; sexual health and family planning; prevention and treatment of sexually transmitted diseases and cancer; infertility treatment; safe abortion; prohibition of all forms of discrimination against women (including FGM); adolescent need for proper nutrition and education; and health care during the perinatal period. The questionnaire included open-ended, close-ended and multiple choice questions about the women's perceptions that were evaluated as 'positive perception' (agreed), 'negative perception' (disagreed) and 'indifferent' (did not know). Women's practices of reproductive rights were assessed as 'yes' (practised) and 'no' (not practised).

The clinic was visited from 09:00 to $13: 30,3$ times per week. Each interview 
was completed within 20-25 minutes. Women were chosen by the sequence of their names in the clinic registration book from which the first 10 women admitted to the clinic daily were interviewed. The aim of the study was explained to the women and consent was obtained.

A pilot study was conducted with 100 women to test the content validity of the tool. This group of women was excluded from the study sample. According to the data obtained from the pilot study, the questionnaire was modified and the number of questions decreased from 60 to 50 . A few words and questions were simplified and the interview time was reduced from 30 to 20 minutes.

During data collection, 50 women refused to be interviewed because they had left their children at home. Moreover, no comparable literature about women's rights in Islamic/Arab countries could be found.
Data were verified prior to computerized data entry (SPSS, version 11.0). Descriptive statistics, i.e. frequencies and percentages, were applied. Testing hypotheses was done using the chi-squared test. $P$-values less than 0.01 were significant.

\section{Results}

Of the 1000 women, $32 \%$ were aged 25 30 years, $51 \%$ were $>30$ years and $17 \%$ were $20-24$ years. The majority were from urban areas with only a few $(9 \%)$ from rural areas. Only $18 \%$ were illiterate, $14 \%$ had primary school education, $30 \%$ had secondary school education, and one-third had university education. The majority had positive perceptions of these reproductive rights: marriage and having a family; family planning; prevention and treatment of sexual diseases and cancer; treatment of

\begin{tabular}{|c|c|c|c|c|c|c|}
\hline \multirow[t]{2}{*}{ Women's right to: } & \multicolumn{2}{|c|}{ Positive $^{a}$} & \multicolumn{2}{|c|}{ Indifferent" } & \multicolumn{2}{|c|}{ Negative $^{\mathbf{a}}$} \\
\hline & No. & $\%$ & No. & $\%$ & No. & $\%$ \\
\hline Marry and have a family & 942 & 94.2 & 8 & 0.8 & 50 & 5.0 \\
\hline Sexual health & 810 & 81.0 & 90 & 9.0 & 100 & 10.0 \\
\hline Use of family planning methods & 900 & 90.0 & 64 & 6.4 & 36 & 3.6 \\
\hline $\begin{array}{l}\text { Prevention and treatment of STDs } \\
\text { and cancer }\end{array}$ & 900 & 90.0 & 18 & 1.8 & 82 & 8.2 \\
\hline Treatment of infertility & 980 & 98.0 & 20 & 2.0 & 0 & 0.0 \\
\hline Safe abortion & 800 & 80.0 & 92 & 9.2 & 108 & 10.8 \\
\hline $\begin{array}{l}\text { Prohibition of all forms of discriminati } \\
\text { against women including FGM }\end{array}$ & 630 & 63.0 & 70 & 7.0 & 300 & 30.0 \\
\hline Adolescent nutrition/education & 978 & 97.8 & 22 & 2.2 & 0 & 0.0 \\
\hline Heatth care during perinatal period & 974 & 97.4 & 26 & 2.6 & 0 & 0.0 \\
\hline
\end{tabular}

-Positive = agreed that women had the right; indifferent $=$ did not know if women had the right; negative = disagreed that women had the right.

$S T D=$ sexually transmitted disease.

$F G M=$ female genital mutilation.

المهلة الصحهية لثثرق المتوسط، منظمة الصحة العالمية، النهلد التاسع، العلد ب، بr. r. 
infertility; health care during the perinatal period; and the right of adolescents to education and nutrition (Table 1). One-third had negative perceptions of the prohibition of all forms of discrimination against females, including the prohibition of FGM. Only $81 \%$ of the women had a positive perceptions of sexual health as a reproductive right, while few had indifferent and negative perceptions towards their reproductive rights.

The percent of women who agreed with the right to choose a husband increased with increasing level of education (Table 2). Illiterate women were least likely to agree with the right to choose a husband $(85.9 \%)$ and university-educated women were most likely $(98.4 \%)$. Differences according to education were statistically significant $(P<0.01)$. Women living in urban areas were significantly more to likely to agree with the right to choose a husband than those living in rural areas (95.8\% versus $77.8 \%, P<0.01)$.

As the level of education increased, perceptions of the suitable age at marriage also increased, that is, only $3.3 \%$ of illiterate women stated that the suitable age for marriage was older than 25 years compared with $4.4 \%$ of women with primary education, $4.6 \%$ of women with secondary education and $10.6 \%$ of women with university education. Differences according to education were statistically significant $(P<0.01)$. Women living in urban areas were more likely to choose higher ages as suitable for marriage than were women living in rural areas. Of those

Table 2 Women's demographic characteristics and their concepts and practices of marriage and having families

\begin{tabular}{|c|c|c|c|c|c|c|c|c|c|c|c|c|}
\hline \multirow[t]{3}{*}{ Concept or practice } & \multicolumn{8}{|c|}{ Education } & \multicolumn{4}{|c|}{ Residence } \\
\hline & \multicolumn{2}{|c|}{$\begin{array}{l}\text { Illiterate } \\
(n=184)\end{array}$} & \multicolumn{2}{|c|}{$\begin{array}{c}\text { Primary } \\
(n=136)\end{array}$} & \multicolumn{2}{|c|}{$\begin{array}{c}\text { Secondary } \\
(n=302)\end{array}$} & \multicolumn{2}{|c|}{$\begin{array}{l}\text { University } \\
(n=378)\end{array}$} & \multicolumn{2}{|c|}{$\begin{array}{l}\text { Urban } \\
(n=910)\end{array}$} & \multicolumn{2}{|c|}{$\begin{array}{c}\text { Rural } \\
(n=90)\end{array}$} \\
\hline & No. & $\%$ & No. & $\%$ & No. & $\%$ & No. & $\%$ & No. & $\%$ & No. & $\%$ \\
\hline \multicolumn{13}{|c|}{ A woman has the right to choose her husband } \\
\hline Correct & 158 & 85.9 & 124 & 91.2 & 288 & 95.4 & 372 & 98.4 & 872 & 95.8 & 70 & 77.8 \\
\hline Incorrect & 26 & 14.1 & 12 & 8.8 & 14 & 4.6 & 6 & 1.6 & 38 & 4.2 & 20 & 22.2 \\
\hline Statistical test & \multicolumn{8}{|c|}{$\chi^{2}=38.67, P<0.01$} & \multicolumn{4}{|c|}{$\chi^{2}=49.2, P<0.01$} \\
\hline \multicolumn{13}{|c|}{ Suitable age formarriage (years) } \\
\hline $16-20$ & 118 & 64.1 & 86 & 63.2 & 134 & 44.4 & 74 & 19.6 & 350 & 38.5 & 62 & 68.9 \\
\hline $21-25$ & 60 & 32.6 & 44 & 32.4 & 154 & 51.0 & 264 & 69.8 & 494 & 54.3 & 28 & 31.1 \\
\hline$>25$ & 6 & 3.3 & 6 & 4.4 & 14 & 4.6 & 40 & 10.6 & 66 & 7.3 & 0 & 0.0 \\
\hline Statistical test & \multicolumn{8}{|c|}{$\chi^{2}=144.5, P<0.01$} & \multicolumn{4}{|c|}{$\chi^{2}=33.3, P<0.01$} \\
\hline \multicolumn{13}{|c|}{ Who chose the woman's husband } \\
\hline Parents & 78 & 42.4 & 50 & 36.8 & 72 & 23.8 & 76 & 20.1 & 228 & 25.1 & 48 & 53.3 \\
\hline Relatives/friends & 62 & 33.7 & 30 & 22.1 & 88 & 29.1 & 138 & 36.5 & 306 & 33.6 & 12 & 13.3 \\
\hline Self & 44 & 23.9 & 56 & 41.2 & 142 & 47.0 & 164 & 43.4 & 376 & 41.3 & 30 & 33.3 \\
\hline Statistical test & \multicolumn{8}{|c|}{$\chi^{2}=51.955, P<0.01$} & \multicolumn{4}{|c|}{$\chi^{2}=35.6, P<0.01$} \\
\hline
\end{tabular}

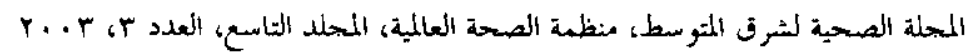


in urban areas, $7.3 \%$ chose suitable age for marriage older than 25 years; no women from rural areas chose this age.

The lowest percentage of those who chose their husbands for themselves was among illiterate women $(23.9 \%)$. Urban women were significantly more likely to have chosen their husbands for themselves than those from rural areas $(41.3 \%$ versus $33.3 \%$ respectively, $P<0.01$ ).

Of women aged 30 to $<35$ years, $76.4 \%$ had correct concepts of the right to discuss sexual heath, whereas only $61.9 \%$ of the 20 to $<25$ years age group had correct concepts (Table 3 ). Of the university-educated women, $85.2 \%$ had cor- rect concepts of the right to discuss sexual life. This percent dropped to $54.4 \%$ of primary educated women and $55 \%$ of illiterate women. Concerning the right to choose the timing of a sexual act, $79.3 \%$ of women aged 30 to $<35$ years had correct concepts in comparison with $88.7 \%$ of women aged 25 to $<30$ years. There were also statistically significant differences between urban and rural women $(P<0.01)$ and among the various levels of education regarding this concept $(P<0.01)$. Of the university-educated women, $88.9 \%$ compared with $71.7 \%$ of illiterate women had correct concepts of their right to choose the timing of a sexual act.

\begin{tabular}{|c|c|c|c|c|c|c|c|c|c|}
\hline \multirow[t]{3}{*}{ Characteristic } & \multicolumn{4}{|c|}{$\begin{array}{l}\text { Right to discuss } \\
\text { sexual life }\end{array}$} & \multicolumn{4}{|c|}{$\begin{array}{l}\text { Right to choose } \\
\text { timing of sexual act }\end{array}$} & \multirow{3}{*}{$\begin{array}{c}\text { Total } \\
(n=1000) \\
\text { No. }\end{array}$} \\
\hline & \multicolumn{2}{|c|}{$\begin{array}{l}\text { Correct } \\
(n=680)\end{array}$} & \multicolumn{2}{|c|}{$\begin{array}{l}\text { Incorrect } \\
(n=320)\end{array}$} & \multicolumn{2}{|c|}{$\begin{array}{l}\text { Correct } \\
(n=814)\end{array}$} & \multicolumn{2}{|c|}{$\begin{array}{l}\text { Incorrect } \\
(n=186)\end{array}$} & \\
\hline & No. & $\%$ & No. & $\%$ & No. & $\%$ & No. & $\%$ & \\
\hline \multicolumn{10}{|l|}{ Age (years) } \\
\hline $20-<25$ & 104 & 61.9 & 64 & 38.1 & 126 & 75.0 & 42 & 25.0 & 168 \\
\hline $25-<30$ & 214 & 67.3 & 104 & 32.7 & 282 & 88.7 & 36 & 11.3 & 318 \\
\hline $30-<35$ & 214 & 76.4 & 66 & 23.6 & 222 & 79.3 & 58 & 20.7 & 280 \\
\hline $35+$ & 148 & 63.2 & 86 & 36.8 & 184 & 78.6 & 50 & 21.4 & 234 \\
\hline Statistical test & \multicolumn{4}{|c|}{$\chi^{2}=14.5, P<0.01$} & \multicolumn{4}{|c|}{$\chi^{2}=17.7, P<0.01$} & \\
\hline \multicolumn{10}{|l|}{ Residence } \\
\hline Urban & 628 & 69.1 & 282 & 30.9 & 752 & 82.6 & 158 & 17.4 & 910 \\
\hline Rural & 52 & 57.8 & 38 & 42.2 & 62 & 68.9 & 28 & 31.1 & 90 \\
\hline Statistical test & \multicolumn{4}{|c|}{$\chi^{2}=4.7, P<0.05$} & \multicolumn{4}{|c|}{$\chi^{2}=10.2, P<0.01$} & \\
\hline \multicolumn{10}{|l|}{ Education } \\
\hline Illiterate & 102 & 55.4 & 82 & 44.6 & 132 & 71.7 & 52 & 28.3 & 184 \\
\hline Primary/preparatory & 74 & 54.4 & 62 & 45.6 & 114 & 83.8 & 22 & 16.2 & 136 \\
\hline Secondary & 182 & 60.3 & 120 & 39.7 & 232 & 76.8 & 70 & 23.2 & 302 \\
\hline University & 322 & 85.2 & 56 & 14.8 & 336 & 88.9 & 42 & 11.1 & 378 \\
\hline Statistical test & \multicolumn{4}{|c|}{$\chi^{2}=84.5, P<0.01$} & \multicolumn{4}{|c|}{$\chi^{2}=30.1, P<0.01$} & \\
\hline
\end{tabular}

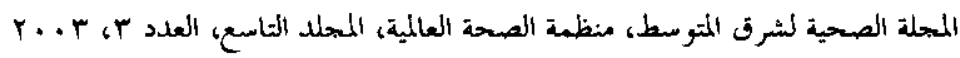


Of all 1000 women, 738 had correct concepts about family planning and used these services, while 226 had correct concepts but did not use the services. Most believed that family planning services were easily obtained. No statistically significant difference was observed between the women's concepts of family planning as a reproductive right and their use of the service (Table 4).

The relationships between education and awareness of and use of screening techniques are given in Table 5. At the university level, $41.3 \%$ of women were aware of STDs and visited doctors for treatment, while $38 \%$ were aware but did not visit doctors. The number of women with no history of STDs was double among university-educated women than among illiterate women. Few illiterate women compared with more than onethird of university-educated women were aware of and had a cervical smear taken. Half of the university-educated women were aware of cervical smears but did not use such screening, while $23.1 \%$ of illiterate women were not aware of it. Less than half of university-educated women were aware of and practiced breast self-examination compared with only a few illiterate women.

A statistically significant association was seen between concepts of FGM and education $(P<0.01$, Table 6). Only $19.6 \%$ of illiterate women considered female circumcision as 'incorrect', whereas FGM was considered incorrect by $23.5 \%$ of primary-educated women, $35.8 \%$ of secondary-educated women and $43.3 \%$ of university-educated women. The mother was the main decision-maker about FGM.

Those who never used antenatal care services were more common among the illiterate $(41.3 \%)$ and the primary-educated $(52.9 \%)$ than among those who had secondary level education $(29.1 \%)$ or university education $(13.8 \%)$. Differences according to education were statistically significant $(P<0.01)$. Almost all stated that they received health care during delivery:

\begin{tabular}{|c|c|c|c|c|c|}
\hline \multirow[t]{3}{*}{ Concepts } & \multicolumn{4}{|c|}{ Family planning } & \multirow{3}{*}{$\begin{array}{c}\begin{array}{c}\text { Total } \\
(n=1000)\end{array} \\
\text { No. }\end{array}$} \\
\hline & \multicolumn{2}{|c|}{$\begin{array}{c}\text { Used } \\
(n=762)\end{array}$} & \multicolumn{2}{|c|}{$\begin{array}{l}\text { Not used } \\
(n=238)\end{array}$} & \\
\hline & No. & $\%$ & No. & $\%$ & \\
\hline \multicolumn{6}{|c|}{ Use of family planning methods } \\
\hline Correct concept & 738 & 96.9 & 226 & 95.0 & 964 \\
\hline Incorrect concept & 24 & 3.1 & 12 & 5.0 & 36 \\
\hline Statistical test & \multicolumn{4}{|c|}{$\chi^{2}=1.87, P=0.17$} & \\
\hline \multicolumn{6}{|c|}{ Access to family planning service } \\
\hline Don't know & 66 & 8.7 & 98 & 41.2 & 164 \\
\hline Easy & 634 & 83.2 & 130 & 54.6 & 764 \\
\hline Not easy & 62 & 8.1 & 10 & 4.2 & 72 \\
\hline Statistical test & \multicolumn{4}{|c|}{$\chi^{2}=140.2, P<0.01$} & \\
\hline
\end{tabular}

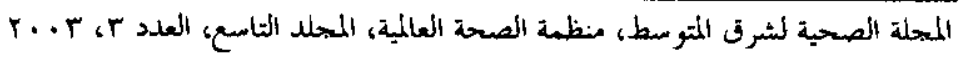


Table 5 Educational level and women's awareness of and practice of screening for STDs and malignancies

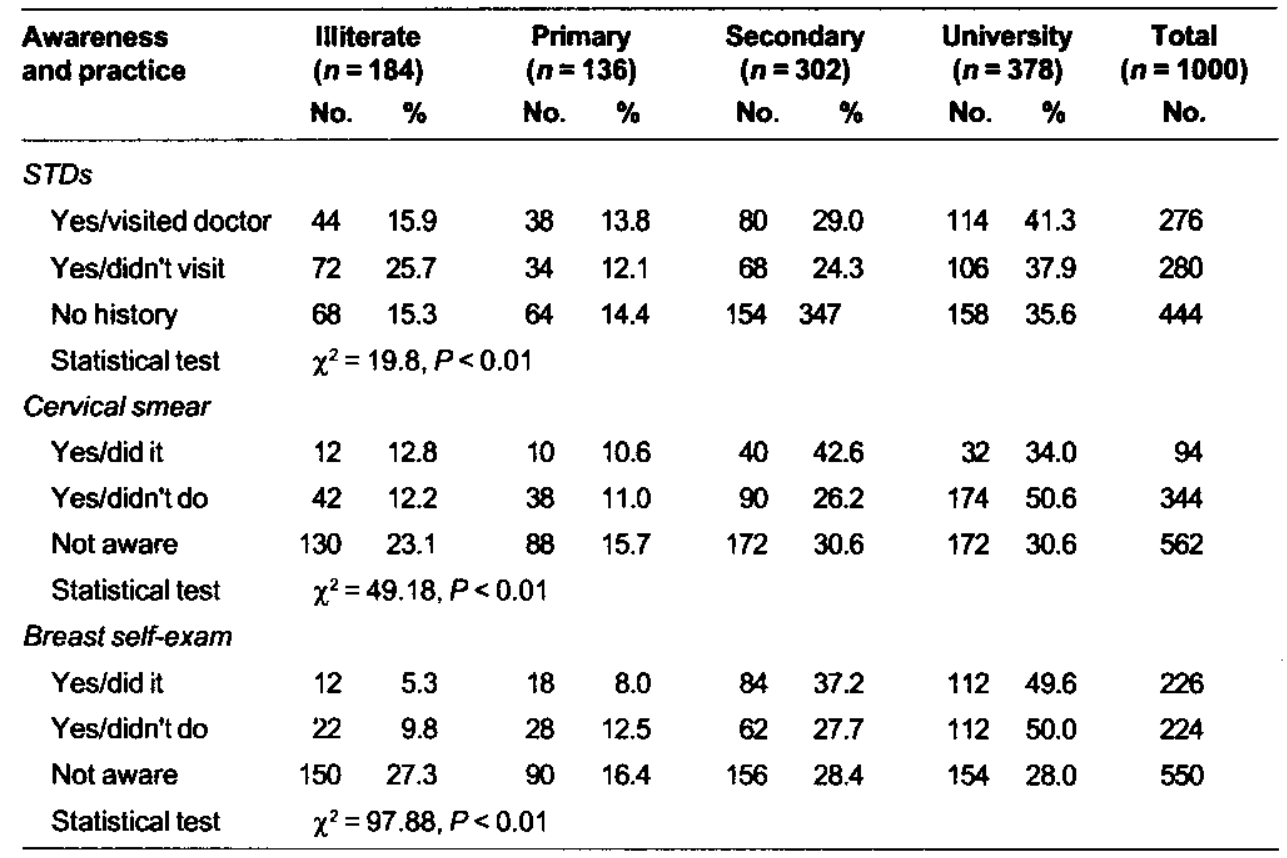

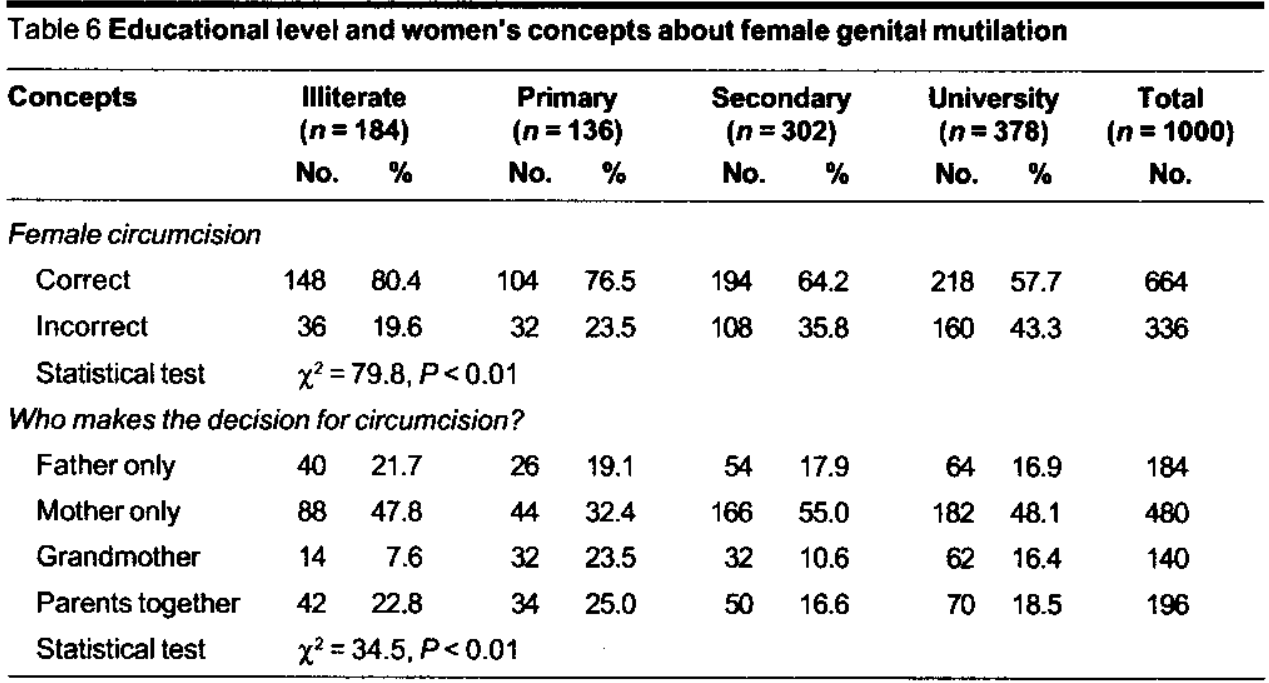

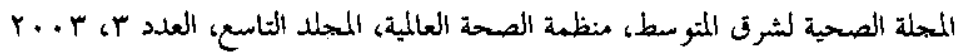




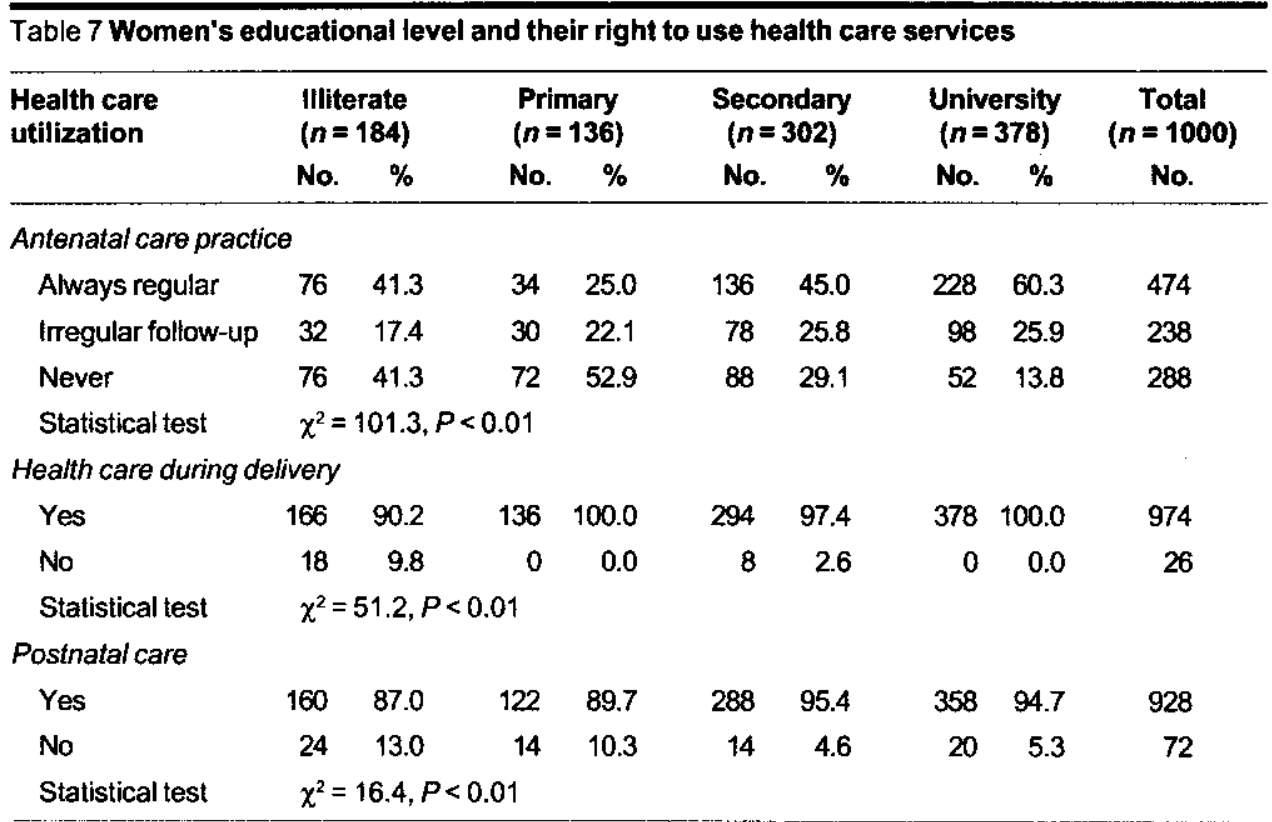

Table 8 Women's education level and concepts of the right of adolescents to proper nutrition and education

\begin{tabular}{|c|c|c|c|c|c|c|c|c|c|}
\hline \multirow[t]{2}{*}{ Concepts } & \multicolumn{2}{|c|}{$\begin{array}{l}\text { Illiterate } \\
(n=184)\end{array}$} & \multicolumn{2}{|c|}{$\begin{array}{l}\text { Primary } \\
(n=136)\end{array}$} & \multicolumn{2}{|c|}{$\begin{array}{c}\text { Secondary } \\
(n=302)\end{array}$} & \multicolumn{2}{|c|}{$\begin{array}{c}\text { University } \\
(n=378)\end{array}$} & \multirow{2}{*}{$\begin{array}{c}\text { Total } \\
(n=1000) \\
\text { No. }\end{array}$} \\
\hline & No. & $\%$ & No. & $\%$ & No. & $\%$ & No. & $\%$ & \\
\hline \multicolumn{10}{|c|}{ Influence of food on reproductive health } \\
\hline Correct & 184 & 100.0 & 134 & 98.5 & 294 & 97.4 & 372 & 98.4 & 984 \\
\hline Incorrect & 0 & 0 & 2 & 1.5 & 8 & 2.6 & 6 & 1.6 & 16 \\
\hline Statistical test & \multicolumn{9}{|c|}{$\chi^{2}=5.1, P<0.16$} \\
\hline \multicolumn{10}{|c|}{ Adolescent education as a reproductive right } \\
\hline Correct & 182 & 98.9 & 136 & 100.0 & 300 & 99.3 & 378 & 100.0 & 996 \\
\hline Incorrect & 2 & 1.1 & 0 & 0.0 & 2 & 0.7 & 0 & 0 & 4 \\
\hline Statistical test & \multicolumn{9}{|c|}{$\chi^{2}=4.76, P=0.19$} \\
\hline
\end{tabular}

$90.2 \%$ of illiterate women, $100 \%$ of primary-educated women, $97.4 \%$ of secondary-educated women and $100 \%$ of university-educated women. The majority stated that they received postnatal care, although this was less common among illiterate and primary-educated women ( $87 \%$ and $89.7 \%$ respectively) than among secondary-educated or university-educated women $(95.4 \%$ and $94.7 \%$ respectively). 
Differences according to education were statistically significant $(P<0.01)$.

The relationship between education and concepts of proper nutrition were statistically significant $(P<0.001)$, but concepts of adolescent education as a reproductive right and educational level were not statistically significant (Table 8).

\section{Discussion}

Long-term neglect of women's reproductive rights has a serious impact on female health in the form of increased maternal mortality and morbidity [13]. We were surprised to find that the majority of women in the present study had positive perceptions concerning their reproductive rights, although a few respondents had indifferent and negative perceptions regarding sexual health and safe abortion as reproductive rights. A very important finding was that demographic characteristics and the right to marry and choose a husband were significantly related. Increases in educational levels were significantly associated with women's decisions to choose their own husbands. In a study of women in Assuit, Qayed [14] also observed this significant relationship between educational level and the right to choose a husband. The majority of women in urban areas in our study had the right to choose their husbands by themselves, but in rural areas the parents chose the husband on behalf of their daughter. This finding fully agreed the El-Zanaty study [15].

Women's demographic characteristics and concepts of the right to sexual health were significantly associated. Most university-educated women had correct concepts whereas only more than half of illiterate women had correct concepts. This was contrary to the Sadik [16] study that reported that discussing sexual life was often difficult in our country as the majority of women felt ashamed to talk about anything related to the issue. In the present study, more than two-thirds of women from urban areas and approximately half from rural areas believed that they had the right to discuss their sexual issues. Most educated women and more than one-third of the illiterate women considered practicing sexual relations at times convenient to the woman a reproductive right. In studies in Chile, Colombia, Kenya, India, Mexico, Pakistan and Thailand, women reported unwanted sexual relations as a major form of physical abuse by their husbands $[17,18]$.

Most women had correct concepts regarding women's reproductive rights to family planning and responded that it was easy to obtain this service. Nonetheless, in some countries including Egypt, laws or programme policies prevent women from obtaining some family planning services without the husband's consent [3]. In several studies in Bangladesh, Ghana, Jordan, Pakistan and Tanzania, women did not participate in decisions about having children, but rather obeyed decisions of their husbands [19].

Many women in the present study had incorrect concepts about the treatment of STDs. Women in rural Egypt have been reported to silently endure reproductive morbidity without complaining of symptoms and to give lower priority to their own health than to that of their husbands and/or children $[11]$. This might be due to economic factors or lack of information [20]. In the current study, educational level and awareness of and practice of screening techniques were significantly related.

The majority of women were circumcised, yet with increasing educational level the procedure was increasingly viewed as an incorrect concept. FGM was nearly

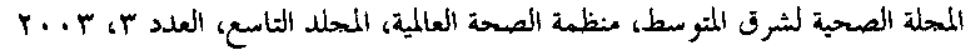


universal among women in Egypt (97\%), Eritrea (95\%) and Mali (94\%) in 1995 and in the Sudan (89\%) in 1998 [2I]. Khattab [II] reported that the main reasons for FGM were Islamic sunna, tradition and social habits. This procedure, however, is not related to Islam and is not done in Islamic countries like the Islamic Republic of Iran, Saudi Arabia or Iraq [22]. The Quran makes no mention, whether explicit or implicit, of FGM and no evidence from religious sources has proven that it is an obligation or a sunna [23]. Overall, no clear doctrinal mandate for female genital cutting has been found in any of the sacred or primary texts of Christianity, Islam or Judaism [24]. Better understanding of Islam is urgently needed to enable females to exercise their right against FGM. In one study, Egyptian women suggested parental education and Sudanese women recommended education campaigns for the eradication of FGM [2l].

The women's level of education and concepts of the right of adolescents to proper nutrition and education were statistically significant. Allah says in the Quran: Eat of the good, which we have provided for you (2:173) and commands us not to overeat or to be wasteful. Less than half of the university-educated women compared with only a few illiterate women had correct concepts about their rights regular antenatal care. In addition, $38 \%$ of the women delivered in a hospital. Perhaps illiterate women trust their midwives, or traditional birth attendants, and feel more secure and comfortable with them.

The primary objective of the next 20 years is to educate women, men and the young about their rights to reproductive choice and sexual health [25]. The Egyptian $\mathrm{NCW}$ is introducing legislation to help eliminate FGM, facilitate the judicial pro- cess in civil affairs (e.g. divorce), adjust the school curricula to correct women's image and eliminate all forms of gender discrimination against women. However, health care providers can play an important role in sensitizing youth, women, men and the elderly to issues of women's reproductive rights in any clinical setting or in the community.

\section{Conclusion}

Most women had positive perceptions regarding their reproductive rights, but negative perceptions were observed regarding the right to prohibit FGM. Women's demographic factors were statistically significant to concepts and practices of sexual health, marriage and having a family, as well as awareness of and practice of screening procedures for the early detection of cancer. We recommend encouraging active participation of men to empower women to exercise their reproductive rights, as well as to enhance women's participation in public life and decision-making. Brochures on women's reproductive rights should be published to disseminate information to youth, men, women and the elderly to increase awareness. Programmes about the reproductive rights of women should be encouraged, stressing the importance of sexual health through religious education as one of the best strategies for the elimination of all forms of discrimination against women and, in particular, FGM. The health team should address the importance of reproductive right issues in health education or counselling at any clinical setting. Further research should be encouraged to investigate men's perceptions concerning women's reproductive rights. 


\section{References}

1. National study on maternal mortality: maternal mortality rates in Egypt. Cairo, Ministry of Health and Population and USAID/John Snow Inc., 2000.

2. Women's health report. Fourth conference on women, Beijing, 1995. Geneva, World Health Organization, 1995.

3. Report of the International Conference on Population and Development, 1994. New York, United Nations, 1994 (A/ CONF.171/13).

4. Cook RJ, Plata MI. Women's reproductive rights. Intemational journal of gynecology and obstetrics, 1994, 46:215-20.

5. Prevention and management of unsafe abortion. New York, Family Care International, 1997.

6. Ragab AR. Reproductive health components and indicators. Cairo, Egypt, 1995:2.

7. Al-Khayat MH. The right path to health. Health education through religion. Health, an Islamic perspective. Alexandria, World Health Organization, Regional Office for the Eastern Mediterranean, 1997:22-34.

8. The NCW official newsletters. Cairo, National Council for Women, 2000:1.

9. Younis $\mathrm{N}$ et al. A community study of gynecological and related morbidities in rural Egypt. Studies in family planning, 1993, 24(3):175-86.

10. Khattab H. Women's perception of sexuality in rural Giza. Monographs in Reproductive Health. Cairo, The Population Council Regional Office for West Asia and North Africa, 1996, 1:3-10.

11. Freedman LP. Human rights and reproductive choice. Studies in family planning, 1993, 24(1):18-21.
12. El-Adawy M, Ragab AR. Reproductive health components and indicators with special reference to Egyptian situation. Cairo, Cairo Demographic Center, 1997:10-22.

13. New directions in reproductive research. Biennial Report of UNDPIUNFPAIWHO. Geneva, World Health Organization, 1998:1-2 (No. 47, pt. 1).

14. Qayed MH. Knowledge, attitude and practice study on reproductive health among adolescents and youth in Assiut governorate. Assuit, National Population Council Development Project, Community Medicine Department, University of Assiut, 1998:15-25.

15. El-Zanaty F. Study on reproductive health concept for advocacy project. Cairo, Ministry of Heaith and Population, 1999.

16. Sadik N. Round table discussion on reproductive health and reproductive rights. New York, United Nations Population Fund, 1998:1-21.

17. Terefe A, Larson CP. Modern contraception use in Ethiopia: does involving husbands make a difference? American journal of public health, 1993, 83(11): 1567-71.

18. Morris L. Sexual behaviour of young adults in Latin America. In: Severy LJ, ed. Advances in population: psychosocial perspectives, vol. 2. London, Jessica Kingsley, 1993:213-52.

19. Nag M. Some cultural factors affecting costs of fertility regulation. Population bulletin of the United Nations, 1984, 17:17-38.

20. Oueda MA. Decision-making regarding reproductive health within the family. Alexandria, Egypt, The Ninth Interna-

المجلة الصحية لشرق المتوسط، منظمة الصحة العالمية، المحلد التاسع، العلد ب، ب. r. 
tional Congress on Women's Health Issues in collaboration with the International Council on Women's Health Issues, Faculty of Nursing, University of Alexandria, 1998.

21. Female genital cutting. Demographic and Health Surveys Program. Calverton, Maryland, Macro International Incorporated, 1997:11.

22. El-Sheneite MF. Female circumcision. Alexandria, Egypt, The Ninth International Congress on Women's Health Issues in collaboration with the International Council on Women's Health Issues, Faculty of Nursing, University of Alexandria, 1998.
23. The right path to health. Health education through religion. Islamic ruling on male and female circumsion. Alexandria, World Health Organization, Regional Office for the Eastern Mediterranean, 1996:34-40.

24. Toubia N. Female genital mutilation: a call for global action. New York, RAINBO, 1995.

25. Dizdarevic-Stojkanovic J. Reproductive health care situation in Bosnia-Herzegovina. Medicine and law, 1999, 18(23):213-5.

\section{Reproductive Health Research Metwork}

We would Ike to draw our readers attention to the Reproductive Health Research Metwork website. Recognizing the importance of reproductive health research as an area of strategic priority for programme and policy development, the WHO Regional Office for the Eastern Mediterranean has created this network for reproductlve health research. The network aims to facilitate exchange of information and research-related experiences in the field for reproductive health between and within countries. The network provides:

1. a comprehensive directory of governmental, private and nongovernmental institutes, scientific bodles, research agencies, advocacy groups, and organizations concerned with and involved in reproductive health research in countries of the Eastern Mediterranean Region;

2. a searchable database on research activities conducted over a specified period of time (1995 to present).

Further information about the network can be obtained at: http:// www.emro. who.int/rhrn/ 